\title{
PENINGKATAN PRESTASI BELAJAR BAHASA INGGRIS MELALUI PEMBELAJARAN JARAK JAUH (PJJ) DALAM PENERAPAN PEMBELAJARAN SINKRON DAN ASINKRON MELALUI GOOGLE CLASSROOM, GOOGLE MEET DAN APLIKASI E-LEARNING
}

\author{
ANDI SULISTIO \\ Madrasah Aliyah Negeri 4 Kediri, Jawa Timur \\ andisulistio53@gmail.com
}

\begin{abstract}
ABSTRAK
Tujuan penulisan Best Practice ini adalah untuk mengetahui peningkatan prestasi belajar Bahasa Inggris terutama siswa kelas XII MAN 4 Kediri selama musim pandemi yang menggunakan pembelajaran sistem daring (dalam jaringan). Penerapan asinkron dengan menggunakan e-learning, grup WA dan sinkron dengan menggunakan google meet dan video conference mampu meningkatkan prestasi belajar bahasa Inggris. Data yang diambil dalam penelitian ini diperoleh melalui observasi pada pembelajaran selama bulan Oktober dan November serta data hasil nilai ulangan harian 1 dan 2. Dari hasil penelitian diperoleh hasil peningkatan aktifitas peserta didik dari 38\% pada minggu ke-1 bulan Oktober menjadi 95\% pada minggu ke-4 bulan November. Peningkatan ini berbanding lurus dengan hasil ulangan harian 1 dengan rata-rata 76,7 menjadi 87,6 pada ulangan harian 2 dengan ketuntasan mencapai 95\%. Dengan demikian dapat dikemukakan bahwa kombinasi pembelajaran daring dengan sinkron dan asinkon mampu meningkatkan prestasi belajar Bahasa Inggris peserta didik.
\end{abstract}

Kata Kunci: Prestasi belajar, Sinkron dan Asinkron, Pembelajaran Jarak Jauh

\section{PENDAHULUAN}

Pembelajaran Jarak Jauh (PJJ) merupakan salah satu kebijakan yang dikeluarkan pemerintah dalam menghadapi pandemi Covid-19 yang sedang mewabah di dunia. Penerapan model pembelajaran ini memang harus dilaksanakan, mengingat pembejaran merupakan kunci utama keberlangsungan sebuah negara. Kerja keras pemerintah dalam menanggulangi wabah yang melanda sangat berpengaruh terdapat pembelajaran khususnya proses yang selama ini berlangsung secara tatap muka berubah drastis menjadi pembelajaran secara daring (dalam jaringan). Dalam masa pandemi ini, ada tiga model pembelajaran yang diterapkan yaitu pembelajaran dalam jaringan (daring), pembelajaran luar jaringan (luring) dan gabungan dari keduanya yaitu pembelajaran kombinasi (gabungan daring dan luring). Proses ketiga model pembelajaran ini merupakan proses baru dalam sistem pembelajaran di tanah air, baik bagi peserta didik maupun pendidik walaupun di negara-negara maju kegiatan pembelajaran seperti ini sudah biasa diterapkan.

Pembelajaran jarak jauh adalah sistem pembelajaran yang dilakukan dimana antara pembelajar dan pengajar tidak berada dalam satu tempat. Sistem ini sebenarnya sudah berlangsung lama. Pada mulanya hanya digunakan oleh orang dewasa dengan sistem korespondensi yang didistribusikan melalui jasa pos, kemudian berkembang seiring adanya radio dan televisi. Pada tahun 1990-an mulai terdapat multimedia dengan menggunakan komputer dan internet. Menurut Undang-Undang nomor 20 tahun 2003 pasal 1 ayat 15, pendidikan jarak jauh adalah pendidikan yang peserta didiknya terpisah dari pendidik dan pembelajarannya menggunakan berbagai sumber belajar melalui tehnologi komunikasi, informasi dan media lain. Sedangkan Keegan dalam buku yang ditulis Warsito menyatakan adanya 5 karakteristik pendidikan jarak jauh yaitu: 1) Adanya keterpisahan pembelajaran yang mendekati unsur permanen antara tenaga pengajar dari perserta didik selama program pendidikan berlangsung, 2) Adanya keterpisahan antara seseorang perserta didik dengan 
perserta didik lainnya selama program pendidikan, 3) Adanya suatu institusi yang mengelolah program pendidikannya. 4) Pemanfaatan sarana komunikasi yang baik sebagai bahan belajar, 5) Penyedian sarana komunikasi dua arah sehingga perserta didik dapat mengambil inisiatif dialog dengan mencari dan mengolah manfaatnya.

Pembelajaran sinkron adalah sistem pembelajaran yang menggunakan jaringan internet dimana antara pendidik dan pembelajar berada dalam satu waktu tanpa jeda. Sistem ini hampir sama dengan sistem pembelajaran tradisional karena baik pendidik maupun peserta didik dapat bertatap muka dan berinteraksi langsung melalui dunia maya. Media yang bisa dipakai dalam pembelajaran ini adalah google meet, video conference dan zoom meeting. Berbeda dengan pembelajaran sinkron, pada pembelajaran asinkron antara pembelajar dan pendidik berada dalam waktu yang berbeda. Pembelajar dalam hal ini peserta didik dapat mengakses materi ataupun informasi yang diberikan pendidik secara fleksibel tanpa terikat waktu. Media yang digunakan dalam pembelajaran model ini biasanya e-learning dan grup whatsapp.

Penerapan pembelajaran jarak jauh ini mulai diterapkan pemerintah pada pertengahan bulan Maret 2020, dimana pada bulan itu telah terjadi penyebaran virus korona yang luar biasa di dunia dengan memakan begitu banyak korban. Langkah awal yang dilakukan pemerintah adalah dengan menyelenggarakan siaran televisi pendidikan yang dilangsungkan di TVRI. Keberadaan siaran ini awalnya cukup membantu terutama untuk pendidikan tingkat dasar. Pada tingkat menengah, kandungan materi yang disampaikan terlalu global sehingga dari sisi materi kurang mendalam. Berakar pada kondisi inilah maka pembelajaran langsung yang disampaikan guru melalui media online tetap dibutuhkan karena bisa menyesuaikan dengan kebutuhan peserta didik.

Wikimedia Indonesia (2020) menyebutkan bahwa media daring adalah media dalam jaringan yang terhubung langsung melalui tehnologi dan internet. Didalam KBBI (2020) juga menyebutkan bahwa media daring terhubung melalui jejaring komputer, internet dan lain sebagainya. Dalam penjelasan ini, daring merupakan suatu keadaan dimana komputer atau alat komunikasi berbasis android saling berkomunikasi dan bertukar informasi dengan tersambung pada jaringan internet. Menurut Yusuf Bilfaqih dan M. Nur Qomarudin (2015) pembelajaran daring merupakan sistem pembelajaran di kelas melaui jaringan untuk menjangkau target pembelajar dalam jumlah yang banyak dan luas. Saat ini, pengertian daring cukup luas, tidak hanya terbatas dalam aspek pembelajaran saja, namun sudah mencakup segala bentuk media komunikasi melaui jaringan internet baik untuk urusan keluarga, pekerjaan maupun dalam pergaulan dalam bentuk facebook, whatsapp, telegram maupun twitter.

Keberlangsungan pembelajaran jarak jauh bagi siswa dan guru merupakan hal baru. Hal ini dikarenakan pada umumnya pembelajaran yang berlangsung di negara kita merupakan sistem tatap muka dimana antara pendidik dan peserta didik berada dalam ruangan yang sama dalam menyelenggarakan pembelajaran. Hal yang baru ini menuntut pendidik menguasi materi ajar yang harus disampaikan ke peserta didik dengan berbagai macam variasi dan beragam model yang menarik agar peserta didik tidak merasa jenuh. Tingkat pencapaian peserta didik ini tentunya tidak dapat disamakan dengan keberhasilan tatap muka. Pada model tatap muka, pendidik bisa langsung berinteraksi dengan peserta didik sehingga kesulitan yang ada dapat dipecahkan secara langsung. Sedangkan pada sistem pembelajaran jarah jauh, pembahasan tingkat kesulitan hanya bisa dilangsungkan melaui tatap muka virtual yang memerlukan media internet dengan jaringan yang stabil. Hambatan-hambatan seperti inilah yang perlu diminimalisir untuk pencapaian hasil belajar yang baik.

Dalam rangka mencapai pembelajaran yang lebih baik, model pembelajaran yang tepat 
adalah sistem daring sinkron dan asinkron. Dalam model pembelajaran ini, guru dapat menerapkan aplikasi google meet, google classroom, whatsapp ataupun video tutorial di you tube. Dengan melalui berbagai fsilitas tersebut peserta didik bisa merasakan suasana pembelajaran bersama karena mereka dapat berkomunikasi secara langsung baik bertanya maupun mengeluarkan pendapat. Keberlangsungan pembelajaran ini merupakan model pembelajaran yang diterapkan di MAN 4 Kediri terutama pada masa pandemi Covid-19.

\section{METODE PENELITIAN}

Dalam pelaksanaan Best Practice ini, penulis menggunakan metode penelitian deskriptif kualitatif. Pemilihan metode ini didasarkan pada kondisi saat ini. Pembelajaran sistem daring yang dilaksnakan dari rumah menuntut pendidik mampu menyampaikan materi pembelajaran dengan berbagai variasi dan metode yang kesemuanya itu berbasis pada online (dalam jaringan). Dalam penelitian ini metode pengambilan data yang dilakukan penulis adalah dokumentasi melalui RPP dan silabus, absensi pada waktu pembelajaran jarak jauh berlangsung, jadwal, foto/screeshoot kegiatan, serta hasil prestasi belajar setelah diadakan evaluasi. Hasil dari penelitian Best Practice ini digambarkan dalam bentuk tabel untuk mempermudah memahami dan mengambil kesimpulan atas penelitian ini.

Pelaksanan penelitian ini dilangsungkan pada semester ganjil tahun pelajaran 2020/2021 pada bulan Oktober hingga bulan Desember 2020 dengan subyek penelitian kelas XII MAN 4 Kediri. Penentuan waktu ini didasarkan pada hasil prestasi belajar pada semester sebelumnya ketika siswa masih duduk di kelas XI. Peristiwa wabah Covid-19 yang berimbas pada dunia pendidkan pada pertengahan Maret 2020 menyebabkan pola belajar yang berbeda dengan sebelumnya, dari tatap muka di dalam ruang kelas berubah menjadi pembelajaran jarak jauh. Dari hasil evaluasi sebelumnya tampak bahwa pola pembelajaran jarak jauh yang diterapkan sangat berpengaruh pada prestasi belajar peserta didik. Adapun media yang dipakai selama pelaksanaan penelitian ini adalah grup whatsapp, google meet, zoom meeting, elearning, serta tutorial melalui you tube. Materi yang disampaikan dalam tiap pertemuan tatap muka virtual ataupun dalam jaringan disesuaikan denga silabus dan lembar kerja yang dimiliki peserta didik.

\section{HASIL DAN PEMBAHASAN}

Perubahan pola pembelajaran yang terjadi secara cepat dan berlangsung lama pada peserta didik sangat berpengaruh terhadap prestasi belajar yang diperoleh. Perubahan ini tidak hanya disebabkan tehnik pemberian materi yang berbeda, namun peserta didik dan pendidik juga dituntut untuk menguasai media pembelajaran yang dipakai. Dalam sistem pembelajaran jarak jauh ini baik peserta didik maupun pendidik harus menggunakan media daring yang membutuhkan jaringan internet yang bagus dan stabil. Keterkaitan antar media dan alat yang dipakai dalam sistem pembelajaran jarak jauh ini tidak bisa dipisahkan satu dengan lainnya. Dalam pembelajaran dengan metode sinkron dan asinkron pemenuhan kuota internet juga merupakan salah satu hal yang utama. Ketika diadakan pertemuan virtual dalam kelas daring, kebutuhan penyerapan kuota lebih besar bila dibandingkan dengan pembelajaran yang hanya bersifat message (pesan) melalui grup. Namun pemahaman yang diperoleh melalui kegiatan virtual ini sangat berbeda dengan system e-learning yang hanya berupa pemberian tugas atau melalui grup whatsapp bahkan media lainnya.

Penelitian yang dilakukan di MAN 4 Kediri ini merupakan kombinasi daring sinkron dan asinkron untuk meningkatkan prestasi belajar bahasa Inggris. Sebelum dilakukan pembelajaran daring dengan metode kombinasi hasil prestasi pembelajaran Bahasa Inggris adalah sebagai berikut: 


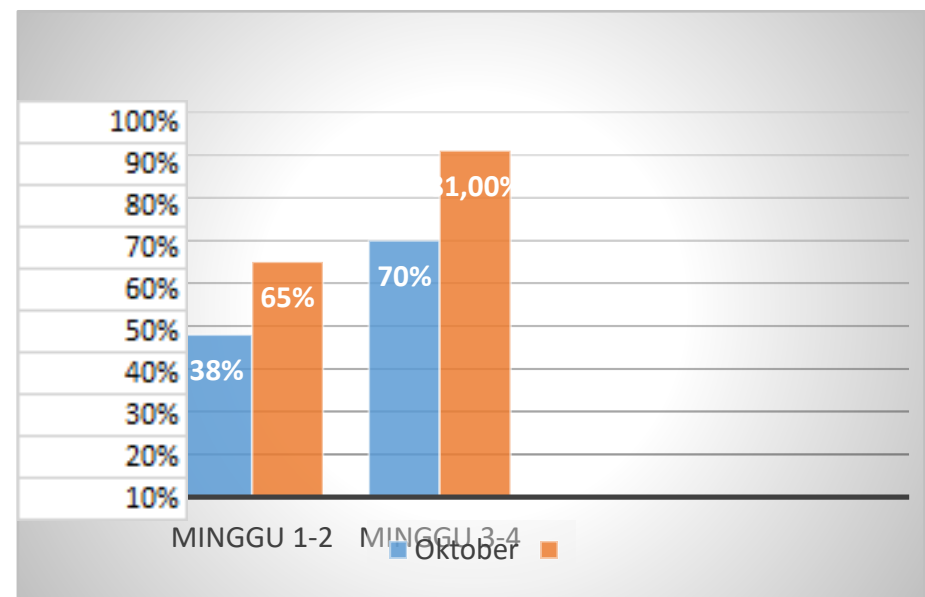

Gambar 1. Grafik Keaktifan siswa dalam bulan Oktober

Grafik diatas menunjukkan keaktifan siswa pada bulan Oktober ketika model pembelajaran daring kombinasi sinkron dan asinkron belum dimaksimalkan. Pada Minggu pertama menunjukkan hanya sedikit siswa yang mengikuti secara aktif pembelajaran yang dilakukan dengan prosentase sebesar 38\%. Pada minggu ini system pembelajaran hanya dilakukan dengan menggunakan e-learning yang merupakan aplikasi dari Kementerian Agama. Pada minggu kedua, peneliti mencoba memberi penguatan dengan cara membentuk grup WA secara lebih intensif. Dalam pembelajaran minggu ini, peneliti tidak hanya menggunakan aplikasi e-learning saja, namun melalui grup WA. Informasi pembaharuan materi pelajaran mulai diberitahukan dalam bentuk pemberian informasi melalui message (pesan). Ketelatenan peneliti mulai tampak hasilnya pada minggu ke 3 dengan hasil sebanyak $70 \%$ siswa mengikuti pembelajaran secara aktif. Hasil ini meningkat pada minggu ke 4 dengan hasil $81 \%$. Hal ini menunjukkan bahwa informasi pembelajaran memerlukan lebih dari satu media untuk mendorong peserta didik secara aktif mengikuti pembelajaran daring.

Paparan diatas juga menunjukkan bahwa tingkat kepedulian peserta berbanding lurus dengan tingkat kepedulian guru. Dalam hal ini apabila guru secara intensif melakukan pembelajaran melalui berbagai media dalam menyampaikan materi ajar terbaru sangat berpengaruh terhadap keaktifan peserta didik juga. Semakin sering guru melakukan pendekatan maka semakin bagus pula respon yang diperoleh.

Pada masa pandemi ini guru dituntut untuk mampu mengedukasi peserta didik dengan berbagai cara agar mereka tidak jenuh dalam belajar. Penyampaian materi yang harus dikuasai peserta didik dapat melalui you tube, e-learning, google meet maupun grup WA. Dalam rangka meningkatkan keaktifan peserta didik dalam mengikuti pembelajaran, peneliti mulai melakukan model sinkron dan asinkron pada bulan November. Hal ini dikarenakan pada minggu ke-4 bulan Oktober, keaktifan siswa sudah cukup bagus dengan perolehan $81 \%$ siswa sudah aktif dalam pembelajaran sebagaimana ditunjukkan pada tabel 1.1. 
Tabel 1.1 Hasil temuan pada bulan November dapat dilihat dari tabel berikut ini

\begin{tabular}{|c|c|c|c|c|}
\hline Bulan & Pertemuan & $\begin{array}{c}\text { Prosentase } \\
\text { Keaktifan Peserta } \\
\text { Didik }\end{array}$ & Rata-rata & $\begin{array}{c}\text { Kategori } \\
\text { Keaktifan }\end{array}$ \\
\hline \multirow{3}{*}{ Oktober } & 1 & $38 \%$ & \multirow{2}{*}{$63,5 \%$} & \multirow{2}{*}{ Cukup } \\
\cline { 2 - 3 } & 2 & $65 \%$ & & \\
\cline { 2 - 3 } & 3 & $70 \%$ & & \multirow{2}{*}{$85,75 \%$} \\
\hline \multirow{3}{*}{ November } & 4 & $81 \%$ & & \\
\cline { 2 - 3 } & 1 & $78 \%$ & & \\
\cline { 2 - 3 } & 2 & $82 \%$ & & \\
\cline { 2 - 3 } & 4 & $90 \%$ & & \\
\hline
\end{tabular}

Dari data diatas terlihat bahwa ada perbedaan yang cukup signifikan pada bulan Oktober dan bulan November. Pada bulan Oktober guru masih menerapkan model asinkron melalui grup WA maupun e-learning dengan hasil rata-rata $63,5 \%$ siswa aktif mengikuti pembelajaran. Hasil itu meningkat pada bulan November dengan perolehan angka rata-rata sebesar 85,75\%. Data diatas menunjukkan bahwa kombinasi kegiatan daring dengan pertemuan secara virtual mempengaruhi tingkat ketertarikan siswa didalam proses pembelajaran.

Keaktifan peserta terendah terdapat pada pertemuan 1 di bulan Oktober. Pada saat itu siswa belum terbiasa mengikuti pembelajaran jarak jauh. Pembiasaan yang sulit seperti ini memerlukan dorongan dan strategi untuk menumbuhkan rasa keingintahuan maupun tanggung jawab pada anak. Masa-masa awal itu merupakan masa transisi atau perubahan dari yang semula terbiasa tatap muka dengan gurunya harus melakukan pembelajaran secara mandiri. Namun demikian, setelah dilakukuan pendekatan dengan baik, pada minggu 2, 3, dan 4 keaktifan siswa sudah mulai meningkat walaupun belum diterapkan pembelajaran tatap muka virtual pada bulan itu.

Peningkatan keaktifan siswa terjadi pada bulan November. Pada bulan ini peneliti sudah mulai menerapkan sistem kombinasi baik sinkron mauun asinkron. Pada saat sinkron, peneliti menggunakan Google Meet karena dianggap aplikasi ini yang paling terjangkau bagi peserta didik. Dalam pertemuan virtual ini guru maupun peserta didik dapat bertemu secara langsung, saling menyapa dan memberi salam satu sama lain yang seakan-akan terjadi reuni karena sudah lama tidak bertemu. Kegiatan seperti ini terjadi ketika guru menerapkannya pada pertemuan virtual di minggu ke 1 bulan November, sehingga pada minggu itu guru tidak memberi pelajaran secara penuh materi pembelajaran karena sebagaian waktu dipakai sebagai sarana chatting dan temu kangen agar keakraban diantara mereka terjalin kembali. Pendekatan ini perlu dilakukan untuk menumbuhkan motivasi kebersamaan dan juga semangat belajar baru bagi mereka.

Dengan memberikan keleluasaan pada minggu pertama di bulan November itu, peningkatan keaktifan siswa menjadi bertambah pada minggu ke 2. Dalam minggu ini, guru sudah memberikan materi pembelajaran secara utuh, disertai dengan tugas yang harus dikerjakan secara mandiri. Keaktifan peserta didik pada minggu 2, 3, dan 4 juga menunjukkan tren yang baik dimana minggu ke 2 menunjukkan angka sebesar $82 \%$ peserta didik mengikuti pembelajaran dengan aktif dan meningkat pula $90 \%$ pada pertemuan minggu ke 3 . Hasil yang cukup tinggi terjadi pada minggu ke 4 dengan keaktifan peserta didik berada pada prosentase 93\%. Hasil ini menunjukkan bahwa penerapan sinkron dan asinkron dalam pembelajaran daring sangat diminati peserta didik karena mereka mempunyai kesempatan untuk bertemu langsung dengan gurunya dan juga teman-temannya secara virtual. Kesulitan yang dialami ketika 
pembelajaran mandiri dapat mereka konsultasikan kepada gurunya ketika pertemuan virtual berlangsung.

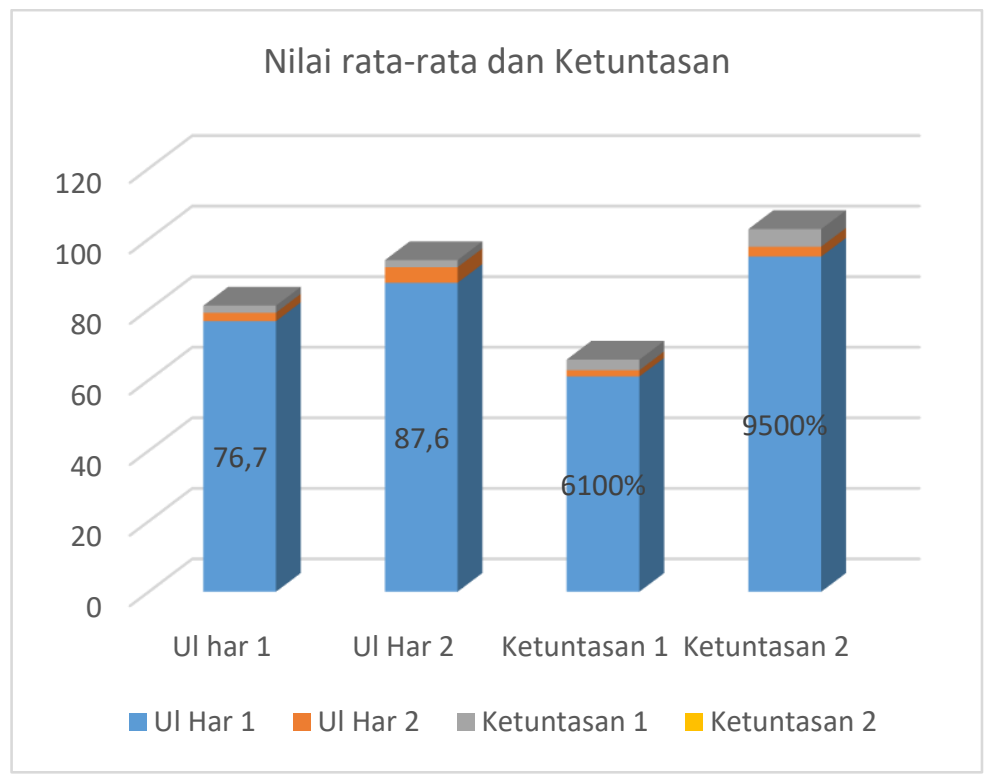

Gambar 2. Grafik hasil ketuntasan belajar

Data diatas menunjukkan adanya peningkatan yang signifikan dari hasil ulangan harian 1. Awalnya rata-rata hasil ulangan harian 1 adalah 76,7 dan ketuntasan sebesar $61 \%$ dengan KKM 75. Rata-rata ini diperoleh dari penilaian pembelajaran yang dilakukan sebelum guru menerapkan metode sinkron dengan hanya melaksanakan pembelajaran melalui grup WA dan pengiriman bahan ajar di e-learning. Pada ulangan harian 2 yang dilaksanakan di akhir bulan November terjadi peningkatan rata-rata nilai menjadi 87,6 dengan ketuntasan sebesar 95\%. Pada bulan November tersebut, guru telah melakukan kombinasi pembelajaran baik sinkron maupun asinkron dan hasilnya menunjukkan peningkatan yang cukup baik.

Hasil temuan penelitian ini senada dengan penelitian yang dilakukan oleh Siti Sumarliyah dari SMK Negeri 4 Denpasar. Penelitian Sumarliyah menunjukkan bahwa peningkatan hasil belajar siswa terjadi setelah dilakukan pembelajaran sinkron dan asinkron. Sumarliyah menunjukkan data ketuntasan klasikal yang semula 69,70\% sebelum dilakukan kombinasai pembelajaran sinkron dan asinkron meningkat menjadi $87,88 \%$ setelah penerapan kombinasi sinkron dan asinkron.

Penelitian terdahulu yang telah dilakukan oleh Sumarliyah (2021) dengan judul "Penerapan Pembelajaran Daring Sinkron dan Asinkron Dengan Menggunakan Google Classroom, Google Meet, Google Slides, Video Tutorial dan Modul Digital untuk Meningkatkan Prestasi Belajar Pelajaran Matematika Kelas XII Perhotelan SMK Negeri 4 Denpasar Tahun Pelajaran 2020/2021" diperoleh hasil bahwa peningkatan nilai rata-rata menjadi 80,85 dari semula 79,97 dengan prosentase ketuntasan sebesar 69,70\% menjadi $87,88 \%$. Perbedaaan mendasar pada penelitian ini adalah banyaknya media yang dipakai dan materi ajar. Peneliti hanya menggunakan 4 media berupa google meet, video conference, grup Whatsapp dan e-learning untuk mata pelajaran Bahasa Inggris, sedangkan Sumarliyah S.Si menggunakan google classroom, google meet, google slide, video tutorial dan modul digital dalam pembelajaran Matematika. Dalam hal ini peneliti hanya menambah penelitian yang sudah ada. 


\section{KESIMPULAN}

Berdasar pada hasil pembahasan, maka dapat dikemukakan bahwa proses pembelajaran dengan menggabungkan model sinkron dan asinkron pada peserta didik kelas XII MAN 4 Kediri, mempunyai dampak yang cukup baik terutama pada peningkatan hasil prestasi belajar yang diperoleh. Pembelajaran asinkron diterapkan terlebih dahulu dengan menggunakan grup WA dan e-learning dan dilanjutkan dengan penggunaan aplikasi google meet maupun video conference.

Data perkembangan hasil peningkatan prestasi belajar bahasa Inggris bermula pada peningkatan aktifitas yang terjadi pada bulan Oktober dari semula 38\% pada minggu pertama meningkat menjadi $93 \%$ pada minggu terakhir bulan November. Peningkatan ini berbanding lurus dengan peningkatan prestasi belajar yang diperoleh dari yang semula nilai rata-rata 76,7 dengan ketuntasan sebesar $61 \%$ pada ulangan harian 1 meningkat menjadi 87,6 dengan ketuntasan $95 \%$ pada ulangan harian 2 yang dilaksanakan pada akhir bulan November.

Dengan hasil penelitian ini, disarankan kepada semua guru pengampu mata pelajaran untuk menerapkan kombinasi model pembelajaran sinkon dan asinkron untuk meningkatkan prestai belajar siswa selama pembelajaran jarak jauh berlangsung. Sedangkan kepada kepala sekolah diharapkan mampu memberikan fasiltas serta pembinaan yang tepat agar pembelajaran jarak jauh yang dilaksanakan mampu memfasilitasi peserta didik untuk tetap semangat dalam belajar dengan hasil berpretasi yang baik.

\section{DAFTAR PUSTAKA}

Arikunto, Suharsimi (2007).Manajemen Penelitian.Jakarta:Rineka Cipta.

Artikel (online). https://guruberbagi.kemdikbud.go.id/artikel/pembelajaran-daring-kemasanproduk/. Diakses tanggal 12 Februari 2021.

Artikel (online). https://idcloudhost.com/mengenal-apa-itu-google-classroom-fitur-fungsidan-keunggulannya/. Diakses tanggal 23 Februari 2021.

Artikel (online). https://guruberbagi.kemdikbud.go.id/artikel/pembelajaran-daring-kemasanproduk/. Diakses tanggal 12 Januari 2021.

Artikel (online). https://idcloudhost.com/mengenal-apa-itu-google-classroom-fitur-fungsi-dankeunggulannya/. Diakses tanggal 13 Januari 2021.

Djamarah, S. B. 2012. Prestasi Belajar dan Kompetensi Guru. Surabaya: Jurnal (online).https://lpmpjambi.id/2020/08/18/belajar-bermakna-dari-rumah-melalui- modelpembelajaran-dasi-assi/. Diakses tanggal 25 Februari 2021.

https://id.wikipedia.org/wiki/Pendidikan_jarak_jauh. Diakses pada 28 Februari 2021

https://online.journal.unja.ac.id/biodik Diakses 14 April 2021

Jurnal (online). https://lpmpjambi.id/2020/08/18/belajar-bermakna-dari-rumah-melaluimodel-pembelajaran-dasi-assi/. Diakses tanggal 10 Januari 2021.

Nurdin Ibrahim, "ICT untuk Pendidikan terbuk Jarak Jauh"jurnal Teknodik, Juni 2005. No. 16:5-18. Jakarta: Pustekkom Depdiknas.

Sumarliyah, 2021. Penerapan Pembelajaran Daring Sinkron Dan Asinkron Dengan Menggunakan Google Classroom, Google Meet, Google Slides, Video Tutorial Dan Modul Digital Untuk Meningkatkan Prestasi Belajar Pelajaran Matematika Kelas XII Perhotelan SMK Negeri 4 Denpasar Tahun Pelajaran 2020/2021. Denpasar: Dinas Pendidikan, Kepemudaan Dan Olahraga Propinsi Bali. Diakses 16 Januari 2021.

Sudjana, N. 2012. Penilaian Hasil Proses Belajar Mengajar. Bandung: Remaja Rosda Karya. UU Sidiknas UU RI Nomer 20 Tahun 2003 Tentang Sistem Pendidikan Nasional, Bab 1 Pasal 1 No. 15 